\title{
Analysis of selected risks arising from human activities in the handling of hazardous waste
}

\author{
J. Betáková ${ }^{1}$, R. Zeman ${ }^{1}$, J. Dvorský ${ }^{2} \&$ T. Pavlenko ${ }^{2}$ \\ ${ }^{I}$ The Institute of Technology and Business in České Budejovice, \\ Czech Republic \\ ${ }^{2}$ Faculty of Security Engineering, The University of Žilina, Slovakia
}

\begin{abstract}
Corporate development and human activity produce waste with different properties. The aim of this study is to identify the risks associated with the handling of selected categories of hazardous waste, to assess their significance and to put forward proposals for measures to reduce the most significant risks. Based on the analysis of the production of hazardous waste in the Slovak Republic, particular attention was paid to the risks arising from human activities in the handling of hazardous waste. Both statistical methods, as well as exact methods of multi-criterial decision-making (scoring method with a map of risk) for risk assessment, were utilized. The result of this study is the evaluation of the perception of risks in the handling of hazardous waste by the citizens of the Slovak Republic and the Czech Republic and the subsequent comparison of the obtained results with those obtained through a multi-criterial decisionmaking assessment method developed by experts based on practice. This study contributes to the extension of the potential scientific - professional platform and focuses on the risks subject to the degree of acceptable risk. The outcome of this study is the evaluation of the most significant risks and proposals for preventive measures to reduce the likelihood of the negative impacts caused by these risks.
\end{abstract} Keywords: risk, hazardous waste, expert assessment.

\section{Introduction}

The Slovak Republic generates a certain quantity of waste that needs attention and it cannot be excluded from our lives, just like any other country in the world. Its breakdown is important in terms of handling such waste quantity. According 
to the Ministry of Environment Decree No. 284/2001 Coll., that establishes a waste catalogue, waste is broken down into two main groups: namely hazardous waste "N" and other waste "O" [1]. The amount of hazardous generated waste is considerably smaller when it is compared to other kinds of waste, but its hazardous properties may seriously endanger the environment and human health. It is necessary to follow the established rules and to handle it as dangerous matter when handling hazardous waste. The quality of the safe handling of hazardous waste may be seriously jeopardized by large amount of risks. The individual risks may result from human activities, the handling of the equipment and the environment in which the manipulation is performed, according to some sources. The most important factor affecting the safety of handling is human activity. It is the activity of people that most often affects the occurrence of an emergency. The aim of this paper is to pay attention to the selected identified risks arising from human activities. It is necessary to determine whether the perception is identical in Slovakia and the Czech Republic and if it is based on the expert risk assessment "Scoring Method to Map Risks" to determine which of these risks are necessary to pay attention to and to propose measures to minimize them. This must be accomplished by using the analysis of variance.

\section{The development of the production of hazardous waste in Slovakia}

We have focused on the development of the production of all kinds of waste in the reporting period from 2005 to 2013 . There are not the data provided from the Statistical Office of the Slovak Republic for 2014 as yet. The specific amount of waste that has been generated in the Slovak Republic was 94,585,169.33 tons from 2005 to 2013. The greatest amount was generated in the Košice Region (KE), specifically $18,961,788.86$ tons of waste. This accounts for $20 \%$ of the total waste for the past nine years. The smallest amount of generated waste was in the Prešov Region (PO) and it was only 6\%, which was 5,594 849.49 tons of waste. This finding is interesting because these regions have the same geographic location. Issues related to unemployment, migration and marginal groups are identical and they are among the lowest ranks in the evaluation in the standard of living in the regions of the Slovak Republic in 2014. Regarding the total quantity of all waste generated in the territory of the Slovak Republic for the period 2005-2013, there was a generation of hazardous waste of $4.40 \%$, which is $4,165,260.96$ tons. The basic statistics data on hazardous waste generation in the region are located on the website of the Ministry of Environment. The largest amount of hazardous generated waste was in the Košice Region i.e. that was $30 \%$ of the total generation of hazardous waste. The smallest generation of hazardous waste was in the Prešov Region, which was 3\% of the total quantity of hazardous waste.

Table 1 shows the generation of hazardous waste per capita of the region in

the year of observation. The values are calculated as the ratio of the generation of hazardous waste and the population belonging to regions and to the same time period. 
Table 1: The generation of hazardous waste per capita (kg) [2].

\begin{tabular}{|c|c|c|c|c|c|c|c|c|c|}
\hline \multirow{2}{*}{ Region } & \multicolumn{7}{|c|}{ The generation of hazardous waste per capita (kg) } \\
\cline { 2 - 12 } & $\mathbf{2 0 0 5}$ & $\mathbf{2 0 0 6}$ & $\mathbf{2 0 0 7}$ & $\mathbf{2 0 0 8}$ & $\mathbf{2 0 0 9}$ & $\mathbf{2 0 1 0}$ & $\mathbf{2 0 1 1}$ & $\mathbf{2 0 1 2}$ & $\mathbf{2 0 1 3}$ \\
\hline BB & 74 & 65 & 52 & 57 & 101 & 89 & 45 & 45 & 58 \\
\hline BA & 115 & 183 & 202 & 271 & 135 & 134 & 97 & 108 & 112 \\
\hline KE & 244 & 241 & 283 & 258 & 334 & 196 & 212 & 140 & 182 \\
\hline NR & 92 & 68 & 34 & 34 & 48 & 60 & 55 & 33 & 32 \\
\hline PO & 21 & 27 & 23 & 16 & 27 & 16 & 16 & 22 & 18 \\
\hline TN & 73 & 89 & 52 & 56 & 49 & 46 & 48 & 98 & 61 \\
\hline TT & 130 & 107 & 86 & 64 & 38 & 41 & 43 & 38 & 9 \\
\hline ZA & 65 & 50 & 91 & 54 & 47 & 90 & 75 & 91 & 86 \\
\hline Average & 100 & 99 & 98 & 94 & 90 & 80 & 71 & 70 & 70 \\
\hline
\end{tabular}

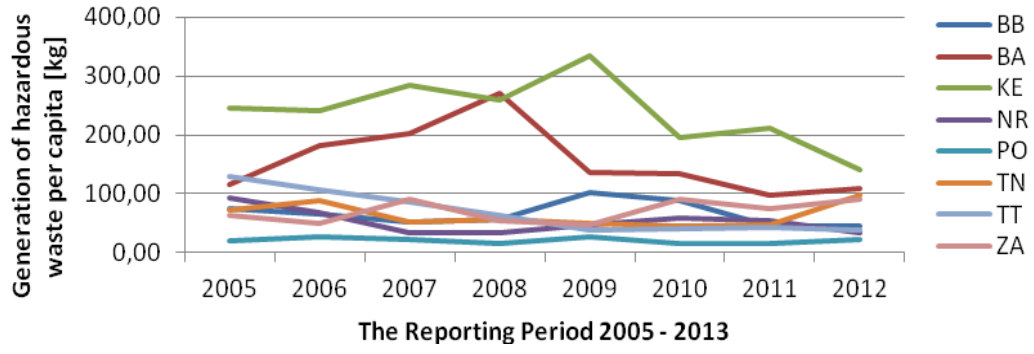

Figure 1: The generation of hazardous waste (HW) per capita in the territorial units of the Slovak Republic.

The paradox is that there has been an increase in the generation of hazardous waste per capita in the Bratislava Region. It grew from $108.52 \mathrm{~kg}$ to $112.34 \mathrm{~kg}$ within 2012 and 2013. The Prešov Region had an upward trend in the production of hazardous waste from 2012 to 2013 , while there was a sharp decline during 2013. Trenčin (TN) doubled its HW generation in 2012 and the values were releveled again in 2013. Banska Bystrica (BB) with Žilina (ZA) have an HW generation oscillating around an average value.

Figure 2 shows the development of the average generation of hazardous waste per capita, expressed in kilograms, from which we can see a downward trend in HW generation. The generation of hazardous waste per capita in the Slovak Republic within the observed period dropped from $99.59 \mathrm{~kg}$ in 2005 to $69.88 \mathrm{~kg}$ in 2013, which represents a $30 \%$ decrease in the amount of hazardous waste generated per capita. The percentage deviation of the generation of hazardous waste shall be calculated as the difference between the actual production of HW and the average generation of HW, expressed as a percentage. Table 2 shows that the percentage deviation is negative for each year in Nitra (NR) and Prešov (PO), i.e. the generation was lower than the average generation of HW per capita. The long-term development shows us that there is a great variability of HW generation across these regions. The Kosice Region (KE) has the highest long- 
term HW generation in the Slovak Republic, but we can see a large internal variability within it; that was more than three times in comparison with an average HW generation per capita in 2009. The HW generation in the region may be partially affected by the number of businesses, such as generating HW US Steel Košice and the like.

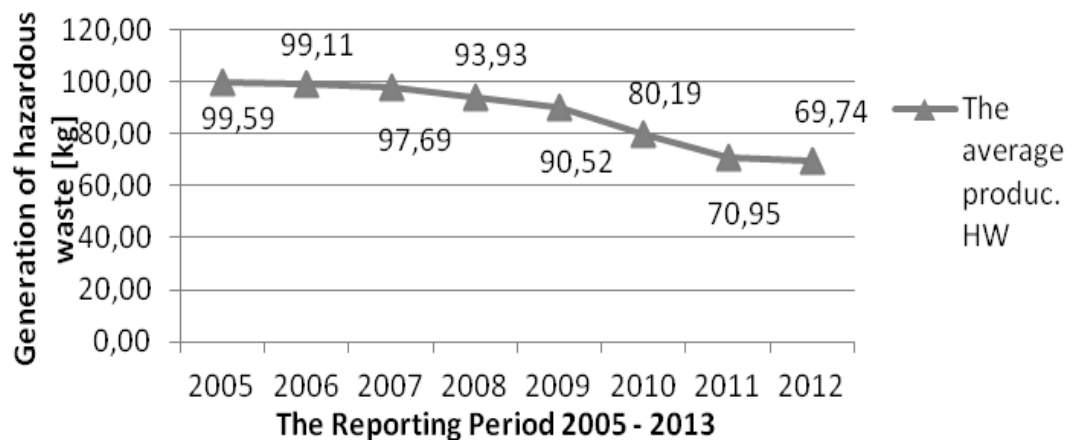

Figure 2: The average generation of hazardous waste per capita.

Table 2: The percentage deviation from the average HW generation from the HW generation per capita.

\begin{tabular}{|c|c|c|c|c|c|c|c|c|c|}
\hline \multirow{2}{*}{ Region } & \multicolumn{8}{|c|}{ The percentage deviation of the HW generation per capita (\%) } \\
\cline { 2 - 11 } & $\mathbf{2 0 0 5}$ & $\mathbf{2 0 0 6}$ & $\mathbf{2 0 0 7}$ & $\mathbf{2 0 0 8}$ & $\mathbf{2 0 0 9}$ & $\mathbf{2 0 1 0}$ & $\mathbf{2 0 1 1}$ & $\mathbf{2 0 1 2}$ & $\mathbf{2 0 1 3}$ \\
\hline BB & -25.9 & -34.5 & -47.4 & -39.2 & 11.8 & 11.2 & -36.2 & -34.4 & -15.9 \\
\hline BA & 15.5 & 84.2 & 107.3 & 189.1 & 49.6 & 67.6 & 36.9 & 55.6 & 60.8 \\
\hline KE & 145.8 & 143.2 & 190.1 & 175.7 & 269.4 & 144.5 & 199.5 & 101.3 & 160.8 \\
\hline NR & -7.2 & -31 & -64.9 & -63.2 & -46.9 & -25.7 & -21 & -52.9 & -54.1 \\
\hline PO & -79.2 & -72.9 & -76.1 & -82.5 & -70 & -80.5 & -77 & -68.2 & -74.1 \\
\hline TN & -26.8 & -10.3 & -46.9 & -40.8 & -46.2 & -43.1 & -32.2 & 40.1 & -13.1 \\
\hline TT & 30.6 & 7.51 & -12.1 & -31.5 & -58 & -48.4 & -38.7 & -45.1 & -87.6 \\
\hline ZA & -35.1 & -49.6 & -7.2 & -42.5 & -48.5 & 12.7 & 5.2 & 30.2 & 23.3 \\
\hline
\end{tabular}

We have noted that there could be a direct correlation between the standard of life of the population and the generation of hazardous waste. The relationship between the population density and the amount of waste is measured by the correlation coefficient, whose formula is the professional mathematical and statistical literature [3].

Figure 3 demonstrates that the highest value of the correlation coefficient was 0.615 in 2008 , which is a medium positive correlation. However, we have observed that between the number of inhabitants and the generation of hazardous waste in that region is the weak dependence in the long term. Positive dependence was observed between the HW generation and the number of firms that generate HW. 


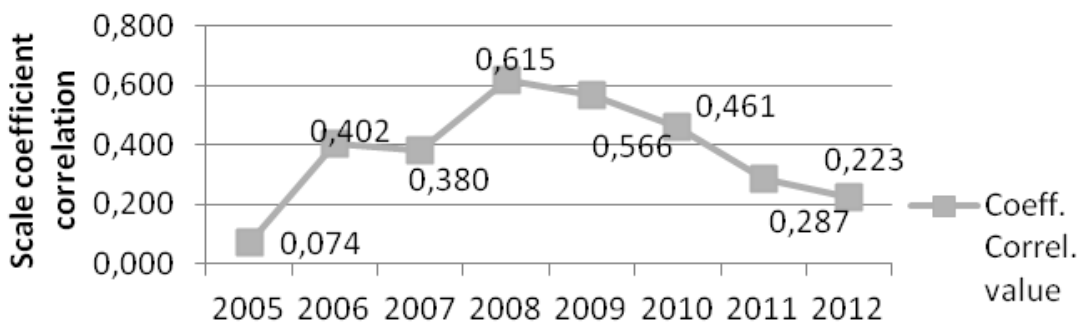

Reporting period 2005 - 2013

Figure 3: The dependence of hazardous waste generation to the population number.

\section{The analysis of the selected risks arising from human activities in the handling of hazardous waste}

Our attention in this paper has been paid to the quantity of the generated hazardous waste per capita. We will deal with the human factors and the risks arising from it in the actual handling of hazardous waste for this reason. The selected risks resulting from human activities are the:

1. poor choice of packaging,

2. incorrect labeling or means of transport,

3. inappropriate choice of route,

4. incomplete ADR special equipment,

5. faulty or failing of the incomplete documentation,

6. breach of traffic rules,

7. wrong mounting and positioning of the packaging in which the waste is stored,

8. health and mental condition of the driver,

9. wrong classification in hazard classes [4].

Using the analysis of variance of the selected risk in Slovakia and the Czech Republic can determined by whether their perception in the countries is identical. A subjective perception of safety by probability values for each of the risk respondents is assigned that identifies a specific risk which may occur (1-10). A comprehensive survey was conducted within the KEGA Project č.005 DTI-42014: The Sectorial Integration of the Spatial Impact of Safety Management of the Environmental Risks based on the survey sample of 360 respondents from the Czech Republic and 360 respondents from Slovakia.

We have used empirical research methods (electronic on-line surveys and standardized written questions by means of a questionnaire), a statistical method that is analysis of variance using quantitative tools of statistics (percentages, averages, variance, homoscedasticita, the Bartlett's test, the KolmogorovSmirnov test, the F-test, the Kruskal-Wallis test, box-and-whisker plot) and statistical software Statgraphics Centurion XVII Statistical Software to meet the stated objective $[5,6]$. 
We have investigated whether the average risks arising from human activities in the handling of hazardous waste by using statistical methods and tools. It is comparable to see whether the nationality of the respondent affects the assessment of selected risks when handling hazardous wastes for the respondents, whether they are from the Czech Republic or Slovakia. We have used the Quantitative Method known as the "ANOVA (analysis of variance)". We have determined the analysis of variance of either a parametric or a nonparametric test. Two basic conditions had to be met for the calculation of the parametric tests, i.e. the resulting $\mathrm{p}$ - the value of a selected risk of a Homoscedasticity test (i.e. the variances of identity) and a test to verify the normality of the selected risks must be greater than a chosen significance level of 0.05 .

The necessary information for the analysis of variance is given in Table 3. These are the basic statistical characteristics of:

$\mu$ - the average of the evaluation of the respondents

$\sigma^{2}-$ the range of respondents' evaluation.

Table 3: The statistical characteristics of the selected risks resulting from human activities.

\begin{tabular}{|c|c|c|c|c|}
\hline \multirow{2}{*}{$\begin{array}{c}\text { Risks arising from } \\
\text { human activities }\end{array}$} & \multicolumn{2}{|c|}{ SR } & \multicolumn{2}{c|}{ ČR } \\
\cline { 2 - 5 } & $\boldsymbol{\mu}$ & $\boldsymbol{\sigma}^{\mathbf{2}}$ & $\boldsymbol{\mu}$ & $\boldsymbol{\sigma}^{\mathbf{2}}$ \\
\hline $\mathbf{1}$ & 4.6 & 3.41 & 4.5 & 3.15 \\
\hline $\mathbf{2}$ & 2.8 & 3.24 & 2.4 & 3.64 \\
\hline $\mathbf{3}$ & 3.1 & 2.56 & 4.1 & 2.40 \\
\hline $\mathbf{4}$ & 5.8 & 0.64 & 5.8 & 1.21 \\
\hline $\mathbf{5}$ & 4.2 & 1.44 & 5.8 & 1.05 \\
\hline $\mathbf{6}$ & 3.1 & 1.69 & 4.7 & 1.13 \\
\hline $\mathbf{7}$ & 2.7 & 3.61 & 5.0 & 2.69 \\
\hline $\mathbf{8}$ & 4.0 & 0.81 & 4.2 & 1.19 \\
\hline $\mathbf{9}$ & 3.3 & 1.34 & 5.1 & 1.24 \\
\hline
\end{tabular}

The analysis of the variance is conducted with a Parametric F Test or with a Non-parametric Kruskal-Wallis Test. A parameter test can be done, only if the two basic conditions are met, i.e. [7, 8]:

- Homoscedasticity: the identity of the variances of the selected risks arising from human activities when handling hazardous waste in different countries. The results are summarized in the Table 4.

- Normality values: a probabilistic model of the normal break-up values assessment of risks arising from human activities when handling hazardous waste in different countries. The results are summarized in the Table 5.

The Nonparametric Kruskal-Wallis Test can be done, if the present homoscedasticity of variances. However, the values of a risk in different sectors do not have a usual break-up [9]. 
Table 4: Bartlett's test to verify the homoscedasticity.

\begin{tabular}{|c|c|}
\hline $\begin{array}{c}\text { Risks arising } \\
\text { from human } \\
\text { activities }\end{array}$ & $\begin{array}{c}\text { Bartlett Test } \\
\text { (P-value) }\end{array}$ \\
\hline $\mathbf{1}$ & 0.051 \\
\hline $\mathbf{2}$ & 0.189 \\
\hline $\mathbf{3}$ & 0.157 \\
\hline $\mathbf{4}$ & 0.219 \\
\hline $\mathbf{5}$ & 0.361 \\
\hline $\mathbf{6}$ & 0.624 \\
\hline $\mathbf{7}$ & 0.501 \\
\hline $\mathbf{8}$ & 0.074 \\
\hline $\mathbf{9}$ & 0.314 \\
\hline
\end{tabular}

Table 5: Pearsonov $\chi^{2}-$ test to verify the normality risks.

\begin{tabular}{|c|c|}
\hline $\begin{array}{c}\text { Risks arising } \\
\text { from human } \\
\text { activities }\end{array}$ & $\begin{array}{c}\text { Pearsonov } \boldsymbol{\chi}^{\mathbf{2}} \\
\text { Test (P-value) }\end{array}$ \\
\hline $\mathbf{1}$ & 0.002 \\
\hline $\mathbf{2}$ & 0.357 \\
\hline $\mathbf{3}$ & 0.018 \\
\hline $\mathbf{4}$ & 0.109 \\
\hline $\mathbf{5}$ & 0.227 \\
\hline $\mathbf{6}$ & 0.097 \\
\hline $\mathbf{7}$ & 0.005 \\
\hline $\mathbf{8}$ & 0.004 \\
\hline $\mathbf{9}$ & 0.188 \\
\hline
\end{tabular}

The results of the results of the Bartlett's Test demonstrate the possibility of how we have accepted that the 0.95 probability of the assumption of the identical variance risks that arise from human activities when handling of hazardous waste in different countries. It has been shown from the Pearson $\chi^{\wedge} 2$-Test that there is a significant level of $5 \%$ of the risks, though 2, 4, 5 and 9 have the usual breakup. All the assumptions in the carrying out of a parametric test F-Test of the analysis of variance are met with these risks. When the P-value of the Pearson Test $\chi^{2}$ for barriers $1,3,6,7$ and 8 are lower than the significance level of 0.05 , we have rejected the assumption of the normal distribution given about the identical variance risks of human activities when handling hazardous waste in different countries. The prerequisites are met for these risks when the nonparametric Kruskal-Wallis test of the analysis of variance is carried out.

The results of the variance analysis of the risks done with a Parametric and a Non-parametric Test are summarized in the Table 6 and the Table 7. 
Table 6: The parametric F-Test of the analysis of the risk variances.

\begin{tabular}{|c|c|}
\hline Barriers & $\begin{array}{c}\text { F-Test } \\
\text { (P-value) }\end{array}$ \\
\hline $\mathbf{2}$ & 0.025 \\
\hline $\mathbf{4}$ & 0.013 \\
\hline $\mathbf{5}$ & 0.001 \\
\hline $\mathbf{9}$ & 0.007 \\
\hline
\end{tabular}

Table 7: The Non-parametric Kruskal-Wallisov test of the analysis of the risk variances.

\begin{tabular}{|c|c|}
\hline Barriers & $\begin{array}{c}\text { Kruskal-Wallisov } \\
\text { Test (P-value) }\end{array}$ \\
\hline $\mathbf{1}$ & 0.008 \\
\hline $\mathbf{3}$ & 0.104 \\
\hline $\mathbf{6}$ & 0.008 \\
\hline $\mathbf{7}$ & 0.001 \\
\hline $\mathbf{8}$ & 0.201 \\
\hline
\end{tabular}

The interpretation of the results of the analysis of the risk variance arising from human activities when handling hazardous waste from Table 6 and Table 7:

We admit with the 0.95 probability of the reliability assumptions about the equality of risk assessment are the:

- inappropriate choice of a route,

- health and mental condition of the driver,

amongst respondents in the Czech Republic and Slovakia. There are no statistically significant differences in the assessment of these risks in terms of a representative statistical sample in the present survey. There are statistically significant differences for other risks arising from human activities when handling hazardous waste in the perception of the respondents between the Czech and Slovak Republics.

\section{The expert risk assessment with the use of the "scoring method with the risk map"}

The selected risks resulting from human activities in the handling of hazardous waste were judged by seven experts dealing with the issue of hazardous waste. The risks were subsequently evaluated by the "Scoring Method with the Risk Map". An assessment table was created for the selected risks which were referred to in the article. The probability values were assigned to each risk, identifying them within which specific risk may occur (from 1 to 10) and the values assessing the impact on the environment and humans (from 1 to 10). The values were averaged after determining the probability and the consequences from all of the experts. The average value of the probability and consequence was subsequently assigned to each risk. The results of the risk assessment 
resulting from human activities in the handling of hazardous waste have been processed in the following Table 8 [10].

Table 8: Risk assessment [11].

\begin{tabular}{|c|c|c|}
\hline $\begin{array}{c}\text { Risk arising from } \\
\text { human activities }\end{array}$ & $\begin{array}{c}\text { Probability } \\
(\mathbf{1}-\mathbf{1 0})\end{array}$ & $\begin{array}{c}\text { Consequence } \\
(\mathbf{1 - 1 0})\end{array}$ \\
\hline $\mathbf{1}$ & 3.6 & 6.4 \\
\hline $\mathbf{2}$ & 3.7 & 3.9 \\
\hline $\mathbf{3}$ & 5.3 & 5.3 \\
\hline $\mathbf{4}$ & 6.1 & 7 \\
\hline $\mathbf{5}$ & 5.3 & 5.4 \\
\hline $\mathbf{6}$ & 4.4 & 8 \\
\hline $\mathbf{7}$ & 5.1 & 8 \\
\hline $\mathbf{8}$ & 4.1 & 7.1 \\
\hline $\mathbf{9}$ & 5.4 & 5.7 \\
\hline
\end{tabular}

The next step of the method is the creation of the risk map as seen in the Figure 4, which shows the corresponding values of the coordinates of the risks, as well as the probability and consequence of the previous table.

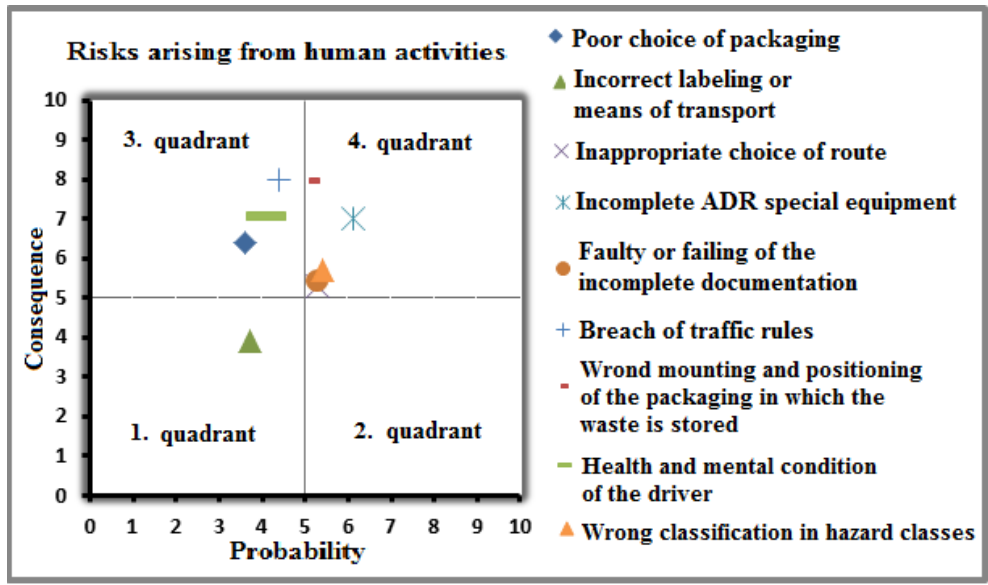

Figure 4: Risk map [11].

The risk map is divided into four equal quadrants when the risks in the first quadrant contained insignificant risks. It is not necessary to minimize these risks according to the procedures methods. The risks (which are located in the third quadrant) contained the significant risks and are the contained critical risks in the fourth quadrant; these are the ones that need attention [10]. It is necessary to develop specific proposals that are applicable in practice for these risks. The proper layout and their application and will reduce the probability and the consequence of a phenomena of crisis in practice. 


\section{Discussion}

The main objective of the present study was to identify the risks involved in the handling of the selected categories of hazardous waste, to assess the significance of the identified risks and to propose appropriate measures in order to reduce the most significant risks. The risks related to the handling of hazardous waste can be reduced by various measures. The least suggestible risks are the health and mental condition of the drivers. It is not easy to establish clear measures in this type of risk. It is possible to put the suggestions in order from the most general to the concrete ones so as to minimize other risks that arise from human activities. Valid suggestions can be given for those risks, such as the violation of traffic rules, the incorrect or incomplete documentation and incomplete special equipment. Concrete measures (in the form of classification methodology) help to prevent the risk of the incorrect classification in hazard classes. Those risks involve such things as the inappropriate choice of route and a poor choice of a package that are closely related to the risk of the incorrectly mounted container in which the waste is stored. Concrete measures can be proposed with these risks with those price offers that are efficient and affordable. The handling of hazardous waste arises from humans associated with a number of others, in addition to the risks that result from handling the means from the environment in which the manipulation is performed. Besides these factors, it is necessary to take the range of risks that arise from the chemical properties of the specific hazardous waste into account.

\section{Conclusion}

The development of hazardous waste was assessed for the period from 2005 to 2013 , depending on the population. The analysis of the variance was used in those selected risks by using quantitative methods. They were comparably identified by the respondents from Slovakia and the Czech Republic: an inadequate route choice, poor health and the psychological condition of the driver. The perception of the risks is identical in both countries. Regardless of this case, the study in Slovakia identified risks evaluated by the mentioned subject matter experts. The results of the experts confirmed a subjective opinion of the citizens who determined the risks that require increased attention, such as an inappropriate choice of route, the health and mental condition of a driver. It is necessary to pay attention to all of the risks based on the results of the "Scoring Method with the Risk Map". They are in the quadrant contained among those important and critical risks.

\section{Acknowledgements}

The authors would like to thank the Ministry of Education of the Slovak Republic for its support in the KEGA Project Grant 005 DTI-4/2014 in cooperation with the Faculty of Security Engineering, University of Zilina. 


\section{References}

[1] Vyhláška č. 284/2001 Z. z. Ministerstva životného prostredia Slovenskej republiky z 11.júna 2001 ktorou sa ustanovuje Katalóg odpadov.

[2] Čiastkový monitorovací systém: Produkcia odpadu a nakladanie s odpadom v Slovenskej republike, Online. http://cms.enviroportal.sk/ odpady/verejne-informacie.php

[3] Lamos, F., Potocký, R., Pravdepodobnost' a matematická štatistika, Bratislava: Vydavatelstvo UK, pp. 125-127, 1998.

[4] Tomek, M., Seidl, M., Halama, L., Bezpečnost' prepravy nebezpečných vecí, Žilina: Hydropneutech, p. 239, 2008.

[5] Statistical office of the Slovak Republic, Statistical Yearbook of the regions of Slovakia 2013, (online). (cit. 2014-7-18), Available at: http://slovak.statistics.sk/

[6] Statgraphics: Software Statgraphics Centurion XVII. 2014. (online). (cit. 1 February 2015). Available: http://info.statgraphics.com/download-trial? \& h hssc $=$ \& hstc\&hsCtaTracking $=\mathrm{d} 8 \mathrm{e} 0219 \mathrm{~d}-8368-487 \mathrm{~d}-\mathrm{a} 39 \mathrm{~b}-8 \mathrm{f} 69849 \mathrm{e}$ $1868 \mid$ ca0011b4-305c-43fe-b137-ea927ae0ac37

[7] Betaková, J., Haviernikova, K., Dvorský, J.: The issues of clusters potential assessing in the regions of Slovak Republic. 2nd International Conference on Management Innovation and Business Innovation, Bangkok, 2014, ISBN 978-981-09-1685-5, pp. 122-127, 2014.

[8] Sipková, L'., Sodomová, E., Modelovanie kvantilovými funkciami, Bratislava: Ekonom, p. 175, 2007.

[9] Betáková, J., Lorko, M., Dvorský J.: The impact of the potential risks of the implementation of instruments for environmental area management on the development of urban settlement, Environmental impact II, Ancona, 2014, ISBN 978-184564762-9, ISSN 17433541, pp. 91-101.

[10] Hudáková, M., Bugánová, K., Míka, V., Metódy a techniky v procese manažmentu rizika, Žilina: EDIS, ISBN 978-80554-0642-8, p. 230, 2013.

[11] Pavlenko, T: Posúdenie významnosti rizík pri manipulácií s nebezpečnými odpadmi. Diplomová práca. Žilina: Fakulta špeciálneho inžinierstva Žilinskej univerzity v Ziline, 2014, p. 108. 